students and staff in the Terrones' nanotech group said "we remain extremely worried that we might be fired on a whim" and that they had been pressured to retract their criticisms of the administration.

Ríos says that the IPICYT administration has offered its full support to the remaining students. The current students declined interview requests from Nature.

Campos, who received her degree, says that she remains shaken by the Terrones' firing. She will soon leave Mexico and head for a postdoctoral fellowship in Brazil. "I don't know if I can or will return, if I have to deal with the people who did this," she says.

That will be a loss for Mexico. During her doctoral training, Campos spent six months in Dresselhaus's lab at MIT, providing a key contribution to a method to enhance graphene nanoribbons for mass production as semiconductors (X. Jia et al. Science 323, 1701-1705; 2009). MIT, in conjunction with IPICYT, applied for a US patent application on the technology, and MIT now is seeking licensing agreements.

\section{Helpful discussions}

Two of the patents that Ríos says the Terrones failed to disclose involve Mexico's largest juice producer, Grupo Jumex in Tulpetlac. The other two are owned by institutions in Japan: the National Institute for Materials Science (NIMS) in Tsukuba and Shinshu University in Wakasato.

The science for the patents was "partly or fully developed" at IPICYT, Ríos wrote, and "it goes without saying how serious stealing intellectual property is".

Gerd Reiband, a head engineer at Jumex, says that the company filed the two patent applications on its own because the work was conducted there, not at IPICYT. There was no agreement to financially reward the Terrones and their names were included as a courtesy for their helpful discussions. Scientists at the two Japanese institutions say similar conditions applied to their patents.

Ajayan Vinu, a materials scientist at NIMS, worked with Mauricio when the Mexican scientist was on a fellowship in Japan. Vinu says that he was astounded to hear that advice that Mauricio had offered had played a part in his dismissal.

"Tell them they are crazy", says Vinu, who was not contacted for details by IPICYT officials. "This is dangerous for science."

The brothers remain in San Luis Potosí and are considering legal action to fight the termination of their employment.

Rex Dalton

See Correspondence, page 160.

\title{
Climate e-mail rerun
}

A HIDING PLACE FOR HIV AIDS virus escapes

treatment inside progenitor blood cells.

go.nature.com/ZGu9wW

Arriving at work on 5 March, Stanford University ecologist Paul Ehrlich found a rambling and highly profane voice message from someone identifying himself as John Q Public. In one of his more lucid moments, the caller labelled Ehrlich and his colleagues in the climate-science community as "progressive communists attempting to destroy America".

Once again, a private e-mail conversation about global warming had gone public, inflaming critics and giving climate scientists yet another lesson in the challenge of responding effectively.

Several days earlier, Ehrlich had taken part in an informal discussion with leading climate researchers on a National Academy of Sciences e-mail list. They were exploring how climate scientists should respond to a recent US Senate report on the 'Climategate' e-mails leaked late last year from the University of East Anglia in the United Kingdom. In the 23 February report, Senator James Inhofe (Republican, Oklahoma), who has long been the leading sceptic in Congress, accused at least 17 climate scientists of unethical, even potentially criminal, behaviour in their handling of climate data.

The researchers' private - and quite spirited - discussion was soon disclosed in conservative media outlets. The initial story, which ran in The Washington Times, quoted Ehrlich as saying that climate scientists must recognize they are in a "street fight against well-funded, merciless enemies who play by entirely different rules". Other participants went so far as to suggest taking out advertisements to counter the sceptics, perhaps through a new non-profit organization.

Ehrlich stands by his statement, but says the affair has made it "crystal clear" that there is no such thing as a private e-mail. "I'm not putting anything in an e-mail that I don't want to appear on the front page of The Washington Times or Fox News," he says, adding that the sceptics "are trying to keep the scientists busy and to keep the scientists from doing their job, and they are doing extremely well".

Stephen Schneider, a climatologist at Stanford University in California who is on Inhofe's list and participated in the National Academy discussion, says he is urging colleagues to calm down and stick to the science. And he hopes that the Inhofe report - which says the scientists "violated fundamental ethical principles governing taxpayer-funded research and, in some cases, may have violated federal laws" will spark a backlash. "If we don't have civil discourse, where reality rather than spin is the basis of decisions, how are we going to function as a society?" Schneider asks.

Yet Schneider himself compares Inhofe to the infamous Senator Joe McCarthy, who led the discredited campaign against communists during the 1950s. Inhofe spokesman Matt Dempsey calls the comparison "flat out false" and says the report merely lists a number of laws - including the Freedom of Information Act and the False Claims Act - that the scientists might have violated. Inhofe has asked the inspectors general of a number of federal science agencies to determine whether iolations actually occurred.

As a member of the minority party, Inhofe can't do much more than issue statements and reports. But Schneider says that if the Republicans later regain a majority in the Senate, Inhofe could take more concrete steps, such as forcing climate scientists to testify before Congress and pursuing his claims in congressional hearings.

Scientific societies, including the American Association for the Advancement of Science (AAAS) and the American Geophysical Union, should respond to Inhofe's report with a declaration of support, says Michael Oppenheimer, a climate scientist at Princeton University in New Jersey who is also on Inhofe's list. "Defending the scientific community and scientists from attacks ought to be a central part of their mission."

The AAAS and other scientific organizations have repeatedly affirmed the fundamental science of global warming, but some officials are wary of responding directly to Inhofe. Alan Leshner, AAAS chief executive, says he is focused on trying to ensure that policy-makers distinguish between the controversies and the science. "What I don't want to see is that this set of incidents is used as an excuse to deny the scientific findings."

Jeff Tollefson

See Editorial, page 141. 